\title{
THE MANUSCRIPTS OF SIR WILLIAM BOWMAN*
}

\author{
by
}

\section{K. BRYN THOMAS}

From time to time there reappear among the archives of great families manuscripts and mementos of their distinguished forebears, and the fortunate investigator is enabled to produce a little new evidence bearing on the lives of great men. In the possession of Sir John Bowman of Newbury are a great number of papers originally belonging to his great grandfather, the illustrious Victorian doctor Sir William Bowman, whose influence upon medical teaching, particularly that of histological anatomy and physiology, and upon the development of ophthalmic surgery, are not, perhaps, nowadays fully appreciated.

Sir John Bowman does not, of course, remember his great-grandfather, though another member of the family, Mr. Humphrey Bowman, now in his eighty-sixth year, has memories of his grandfather which are vivid and clear. He was about thirteen years old when Sir William died and he recalls happy childhood holidays at Sir William's country home near Dorking. Since William Bowman was born in 1816thirteen months after Waterloo-these two lives represent a considerable span of time.

The manuscripts now in the possession of his great-grandson relate both to Sir William Bowman, and to other members of his family, and they are interesting and in some cases remarkable.

Sir William's father was John Eddowes Bowman (1785-1841), the son of a tobacconist of Nantwich, Cheshire. He worked for a time with his father but then went into banking and settled in Nantwich and later Welshpool, Wrexham, and Manchester. He married his cousin Elizabeth Eddowes, and William, the third son and the fourth child, was born on 20 July 1816. John Eddowes Bowman was a notable geologist and naturalist, a Fellow of the Linnaean and Geological Societies and of the Manchester Philosophical Society. Many of his manuscripts and drawings survive among the papers, including a manuscript bound copy, with drawings and maps, of his Tour through the Hebrides, 1825. Sir Charles Lyall, the eminent geologist, wrote of him (Elements of Geology, 1871, p. 382): 'The late Mr. Bowman was the first who gave a satisfactory explanation of the manner in which distinct coal seams, after maintaining their independence for miles, may at length unite, and then persist throughout another wide area with a thickness equal to that which the separate seams had previously maintained.' We find John Eddowes Bowman writing to his son about J. L. R. Agassiz (1807-1873), the Swiss naturalist, who published his Fishes of Brazil in 1830. 'Agassiz', wrote Bowman in 1840, 'has named all Gardner's Brazilian fishes which are only seven species though all new and exceedingly interesting . . . He returned to London but stops at the Marquess of Northampton, or I would have sent the stickleback by him. He will be at the meeting of the Geological Society next Wednesday and will be glad to see you if you will ask Lonsdale to introduce you.'

* From a paper read to the Osler Club of London, 8 January 1965, at King's College Hospital, London. 
The stickleback refers to William Bowman's study of muscles, in which he used this fish. It is obvious that his father's knowledge and interests provided serious scientific background for young William.

William Bowman was born on 20 July 1816 at a house, Sweetbriar Hall, in Hospital Street, Nantwich, Cheshire, which is still standing, though sadly in need of repair.* A water colour of this house (fig. 1) was made by Henry Bowman, his brother, about 1860 , as is stated by a note in William's hand on the reverse of the painting. That William grew into a handsome young man is shown by the sketch (fig. 2) made by his elder brother, Eddowes, in July 1834 when he was just eighteen. (The note is in William Bowman's hand). That he himself was also artistically capable is shown by his own drawing of his younger brother John Eddowes which he himself, much later, dated as ?1833, but which was probably done at the same time in 1834, as there is also an almost identical drawing by Eddowes, the elder brother (fig. 3). This little series of delightful drawings is completed by a copy made by William of a sketch by Eddowes of their sister Elizabeth, who after a happy marriage in 1836 died from eclampsia in childbirth at Abergavenny in 1838, aged 26. There are extant a number of charming letters from Elizabeth to her brother, as well as a sad series between the parents and brothers mourning her death.

The elder brother Eddowes matriculated Master of Arts, and became Professor of Classics at Manchester. He remained unmarried. Henry the second son, the artist of Sweetbriar Hall, became an architect in Manchester, and John Eddowes, the youngest of the five children, was to become well known as Professor of Chemistry at King's College, London.

Of William Bowman's early life we know a good deal from the letters of his parents, and from his own. He went to school in Liverpool at the age of nine, whence he wrote two charming letters (fig. 4). A year later he was transferred to Hazelwood School in Birmingham, whose headmaster was the eccentric but conscientious Thomas Wright Hill, father of the founder of the penny post, Rowland Hill, who also taught in the school.

Bowman went on to become a medical student in Birmingham, where he was apprenticed to W. A. Betts, house-surgeon to the Birmingham Infirmary. At the same time Bowman worked under the aegis of the well-known Birmingham surgeon, Joseph Hodgson (1788-1869) later President of the Royal College of Surgeons of England (1864), the first provincial surgeon to become so.

Admonitory letters were written by his father to Bowman at this, as at most other stages of his career, though there is no doubt of their mutual affection. Here is one written by the father to William at King's College, London, 10 May 1839, in which we hear the value set upon him by his teacher Joseph Hodgson at so early a stage in his career. 'He gave a very favourable report of you ... he had no doubt if you kept going on in the same way, you would in time do very well, and rise high. He was very glad you had gone to K(ing's) C(ollege): he hoped you would continue there: you would be a great goose to leave it. He did not think your religious views were any obstacle to your progress . . . I expressed the great obligations you and I were under for his great and continued kindness to you.'

* A recent newspaper report states that the house has been saved from demolition, and is being repaired. 


\section{The Manuscripts of Sir William Bowman}

Another view of his character at this time is given by a letter to William Bowman from Peyton Blakiston (1801-1878), the Birmingham physician who, in gratitude for Bowman's help in making measurements of the orifices of the heart, had presented him with a Powell microscope, the instrument with which Bowman made his famous histological studies, after he had come to King's College. Blakiston wrote to him on 18 October 1837, 'I will take the opportunity, my dear Bowman, of calling your attention to a point in your own character: though I believe it relates more to manner than to anything deeper-I would suggest that caution seems to me to be allowed too full a scope-as for me you know I have none-but still I think too much caution in the young has the effect of giving an appearance of coldness which does not belong to them-I could wish to see in you a little more warmth of manner for of the warmth of your feelings I have had abundant proof.'

Sententious perhaps, but a comment of interest to us, as throwing light on Bowman's seriousness of character.

In those days the membership of the College of Surgeons, which was Bowman's aim, required a period of attendance at a London teaching hospital. So in October 1837 Bowman left Birmingham for King's College, London, where he became a member of the Medical Department which had been founded in 1831, the foundation of the hospital following in 1839. Undoubtedly the choice of King's was made because of the appointment of Richard Partridge (1805-1873) as Professor of Anatomy. Partridge had been a pupil of Joseph Hodgson in Birmingham, and was later also to become President of the Royal College of Surgeons. He had already been elected F.R.S.

In August 1837, the Rev. James Rose, Principal of King's College, wrote to Partridge 'the account which you give of $\mathrm{Wm}$. Bowman is such as to make him a very desirable inmate of the College. His being a Dissenter will create no difficulty ... It is only a question of whether he himself will object to attending Chapel on Sundays ...' King's College had been founded as a Church of England establishment.

At King's, Bowman worked under John Simon who was prosector to Robert Bentley Todd (1809-1860), Professor of Physiology. In 1838, when Simon became Demonstrator of Anatomy, Bowman took over this post of Prosector to the Physiology Lectures, and thus came closely into contact with Todd, a brilliant teacher who greatly inspired Bowman's work.

The two men worked easily together and there is a letter from Todd to Bowman, written to the latter in France, which is a perfect period piece of chatty and intimate advice, though not of legibility. Such comments as 'I wish you would get me one or two of Becquerel's* needles-with my galvanometer I should think those experiments should take well' and 'Poiseuille* is your haemodynamometer man-he has an instrument for measuring the dilatation of arteries which I should like to see,' show the intimacy between the two men no less than the final advice regarding Bowman's French landlady 'take care of the widow and do not allow yourself to be penetrated by the daughter.' The collaboration of Todd and Bowman on the Cyclopaedia of

* Antoine Becquerel (1788-1878), French physicist, F.R.S. and Copley medallist, 1837. J. L. M. Poiseuille (1799-1869), French physiologist who invented the mercury manometer (haemodynamometer), and repeated Stephen Hale's experiments. His Law of Capillary Movement is fundamental to the measurement of the viscosity of the blood. 


\section{K. Bryn Thomas}

Anatomy and Physiology produced an important contribution to medical teaching, a four volume encyclopaedia published between 1836 and 1852 with a supplement in 1859. It was followed by their Physiological Anatomy and Physiology of Man, published in two parts in 1845 and 1856, another landmark in academic medicine.

In 1838 Bowman went to the continent to visit the hospitals of Paris, Vienna, Germany and Holland. His companion for this journey was Francis Galton (18221911), who had been a fellow pupil under Hodgson, and who later achieved fame as an explorer, and eminence as the father of eugenics. Galton's account of their journey is entertainingly told in his Memories of my Life, 1908, and Karl Pearson, in his Life of Galton, quotes a humorous description of the incident in which, while in Berlin, Galton developed an inflamed ingrowing toenail for which Bowman operated, using a bent pin and pair of scissors, for want of other instruments.

Prior to their journey, however, father Bowman had characteristically written to William, 'To return to young Galton-I infer that his father wishes him to go with you, not exactly perhaps as his tutor, but to be under your charge and superintendence. You say he's an amiable youth otherwise if no remuneration is understood it would not be worthwhile to take such a charge and perhaps impediment: for unless it be the understanding that you are to make all the arrangements and that he is to conform to them and be merely passive there may be risk of difference of opinion ... There is an easy knack of avoiding this, first by planning with foresight and judgement, providing for possible contingencies, acting the leader without any assumption of authority ... strict and stern self-command of temper, disregarding petty annoyances and discomforts, nay rather sporting with them ... and a facility of giving way with a good grace on trivial unimportant points.' Unnecessary advice perhaps, when we consider that young Galton was a cousin of Charles Darwin, and was to become a most energetic and determined explorer in his own right. To William in Germany, John Eddowes Bowman wrote on 17 August 1838, 'I never regretted so much as on these occasions (visits to foreign countries) my inability to sketch with fidelity and freedom and I shall be disappointed if you do not transfer many of these (costumes and customs) into your sketch books.' William certainly followed his father's advice, for one finds among his papers his daily journal, interspersed with the most attractive little drawings of people, places and animals. He also preserved many ephemera, even laundry and restaurant bills, railway tickets and timetables being kept, as well as letters from his family and friends which he received while travelling.

Returning to Bowman's career, we find that he passed his examination of Membership of the Royal College of Surgeons in June 1840, and was elected Fellow in 1844, three years after he had become F.R.S. During these years most of his brilliant histological work was done.

In assisting Richard Bentley Todd with his 'Cyclopaedia' and 'Physiological Anatomy', William Bowman investigated with his microscope the minute structure of the parts he was describing. He found this necessary for the simple reason that it had never been done before. Though he was still only in his twenties all his previous training had made Bowman ideally suited for this task, and his accurate eye and descriptive pen produced masterly accounts of the histology of body tissues; his paper to the Royal Society 'on the minute structure and movements of voluntary muscle' 


\section{The Manuscripts of Sir William Bowman}

was given on 18 June 1840; until the recent advent of the electron microscope histologists have been able to add little to Bowman's original description of striated muscle of 125 years ago.

This work on muscle resulted in his election to the Fellowship of the Royal Society in 1841 , when he was twenty-five. His descriptions of skin, nerves, sense-organs, liver, lungs, kidney and testes, muscle, bone and cartilage, all brought new discoveries and Sir Arthur Keith stated that he knew no parallel to this feat of Bowman's in making so enormous a series of new discoveries while producing material for a new book. The book was The Physiological Anatomy and Physiology of Man, produced by Todd and Bowman in two volumes, 1845, 1856, which d'Arcy Power described as constituting an epoch in physiology. It was the first physiological book in which the histology of the parts was accurately described, and in all cases function was related to anatomical structure-the essential basis of understanding in physiology. A large number of the woodcuts in the book were drawn by Bowman, some of them being made by him directly on the block. This would account for the disappointment now felt in not coming across any of his drawings in the present collection, though presumably he must have made some rough sketches. A solitary find is a delicate ink and wash sketch of Malpighian corpuscles, which may be compared with the plate in the Royal Society paper (figs. 5 and 6). Here we have an original drawing of what is now known as Bowman's capsule, though Bowman himself stated that it had earlier been described by Müller. There is little doubt, however, that the attribution to William Bowman is justly merited. His paper On the Structure and Use of the Malpighian Bodies of the Kidney, with Observations on the Circulation through that Gland was read to the Royal Society in 1842 and earned him the Royal Medal of the Society. It is indeed a profoundly important paper, not only for its content, but for the way in which that content is presented, so that the anatomical features, minutely described, are related to the physiological functions which they perform. Such a concept had a deep influence on contemporary thinking and teaching. Unfortunately no details are given on this sketch, merely directions to the engraver or copier, e.g. 'too broad,' and a not entirely comprehensible note 'Section of footstalk tags, which open into cavity.'

These histological studies of Bowman must appear the more remarkable when we remember and realize the relatively primitive means which was all that he had at his disposal for the preparation of his materials. No highly accurate microtome or staining techniques were available. Delicate structures such as mucous membranes and renal glomeruli were described from specimens whose only treatment was maceration in alcohol or liquor ammoniae, followed by hardening in solution of salts, if they were treated at all.

With the continuation and gradual completion of these studies Bowman began to pass into the next phase of his professional career. He never returned to physiological research, turning to surgery, to ophthalmology, and to the cultivation of his practice.

In 1842 he married Harriet Paget, daughter of a Leicester surgeon*, and no doubt felt the need to settle in a lucrative career. Theirs was a long and happy marriage, and their eldest son, William Paget Bowman, born 25 September 1845, was the grandfather of the present Sir John Bowman.

* Thomas Paget, Surgeon of Leicester; not connected with the famous surgeon Sir James Paget. 


\section{K. Bryn Thomas}

In 1840, aged twenty-four, William Bowman became Assistant Surgeon to King's College Hospital, and sixteen years later was elected surgeon. Not long afterwards he resigned his surgeoncy in order to compete with the claims of an expanding private practice. In 1848 he became joint Professor of Physiology and General Anatomy, Robert Bentley Todd being his co-Professor.

At King's Bowman exerted great influence. It is not perhaps generally realised that it was due to this influence, with that of George Johnson (1818-1896), Professor of Medicine, that Joseph Lister was invited, in 1877, to the Chair of Clinical Surgery at King's College, and to a surgeoncy at the Hospital. This in itself entitles Bowman to the respect of the otherwise dilatory London schools, in recognizing the urgent need to foster Lister's doctrines south of the Border.

Here too, may be mentioned the part which Bowman played in the improvement of nursing at King's College Hospital. With Todd and others, and notably Florence Nightingale, the system was reorganized. In 1854, Miss Nightingale herself considered taking on the Superintendent post at King's. Her contact with Bowman had commenced early in her nursing career, for he was surgeon to the Harley Street Institution for the Care of Sick Gentlewomen, where she had her first nursing post. The Crimea interrupted their plans.

In 1846, Bowman was appointed Assistant Surgeon to Moorfields Eye Hospital, then the Royal London Ophthalmic Hospital, his interest in the anatomy and surgery of the eye having been aroused in prosecuting his histological studies. At this time ophthalmic surgery was regarded as a side-line to be practised by general surgeons. Bowman was the first of a distinguished line of surgeons to specialize in this branch of surgery at Moorfields. Later, of course, other hospitals organized their own departments, that at King's becoming a special department in 1865, Soelburg Wells of Moorfields being the first Professor.

Bowman's original contributions to the surgery and medicine of the eye were many. Histologically he described the cornea, including its anterior elastic membrane, Bowman's membrane: the radial fibres of the ciliary muscle, Bowman's muscle: he was the first in England to make use of Helmholtz's brilliant invention in 1851, the ophthalmoscope; he innovated operations for artificial pupil in 1852, and a new operation for cataract in 1865, in a paper entitled 'On Extraction of Cataract by a Traction Instrument, with Iridectomy; with remarks on capsular obstructions and their treatment', printed in The Ophthalmic Hospital Reports, 1865, 4, 332. The new part of this operation was the improvement of von Graefe's technique; Bowman performed a preliminary iridectomy, thus allowing traction on the lens through a relatively small sclero-corneal incision. In 1857 his paper on the Treatment of Lacrymal Obstructions produced a notable advance in the treatment of this tiresome condition, when he advocated among other ideas the passage of graduated probes into the canaliculus, rather than the horse-hair size which had previously been employed. This paper, which appeared in The Ophthalmic Hospital Reports in October 1857, is a model of the precise way in which Bowman made his observations and expressed his clear deductions therefrom.

The biographical details of Bowman's life may be briefly completed. He was made a baronet in 1884. Previous writers have all commented upon his thoughtfulness and 


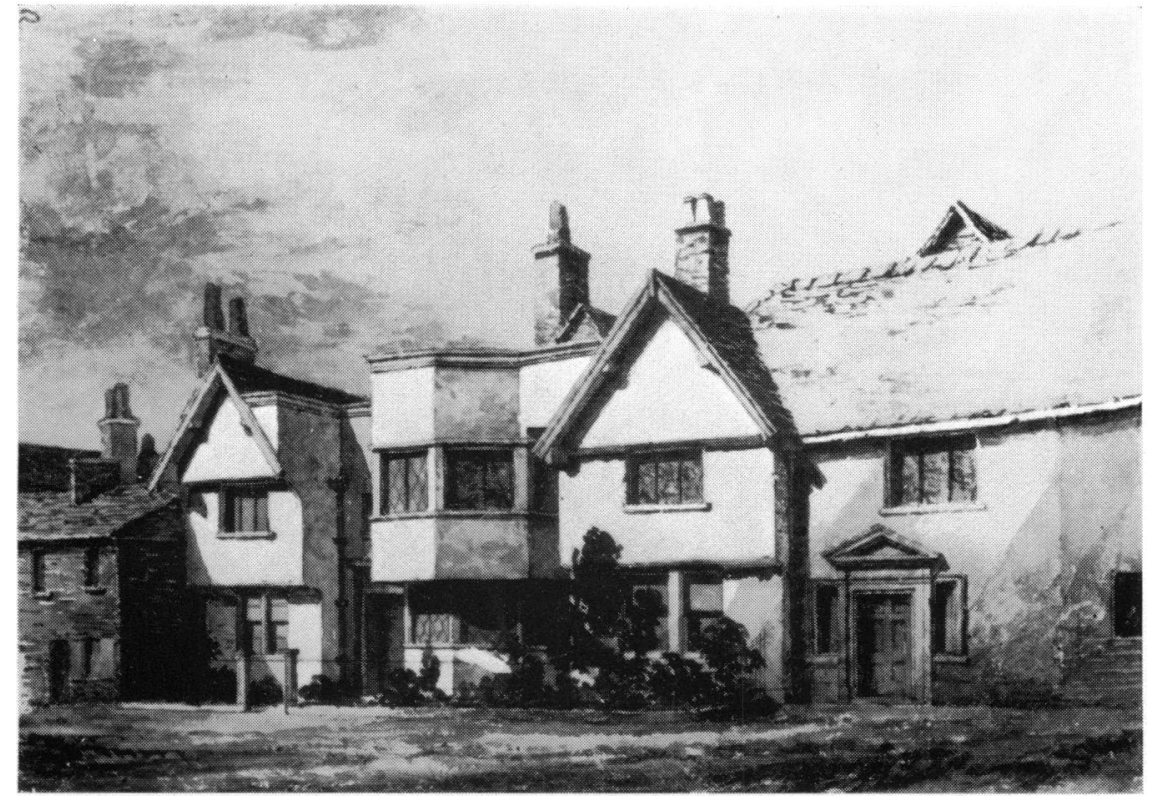

Figure 1

Sweetbriar Hall, Nantwich, Cheshire. Birthplace of William Bowman. (From a watercolour made by Henry Bowman, $c$ 1860.) (see p. 246)

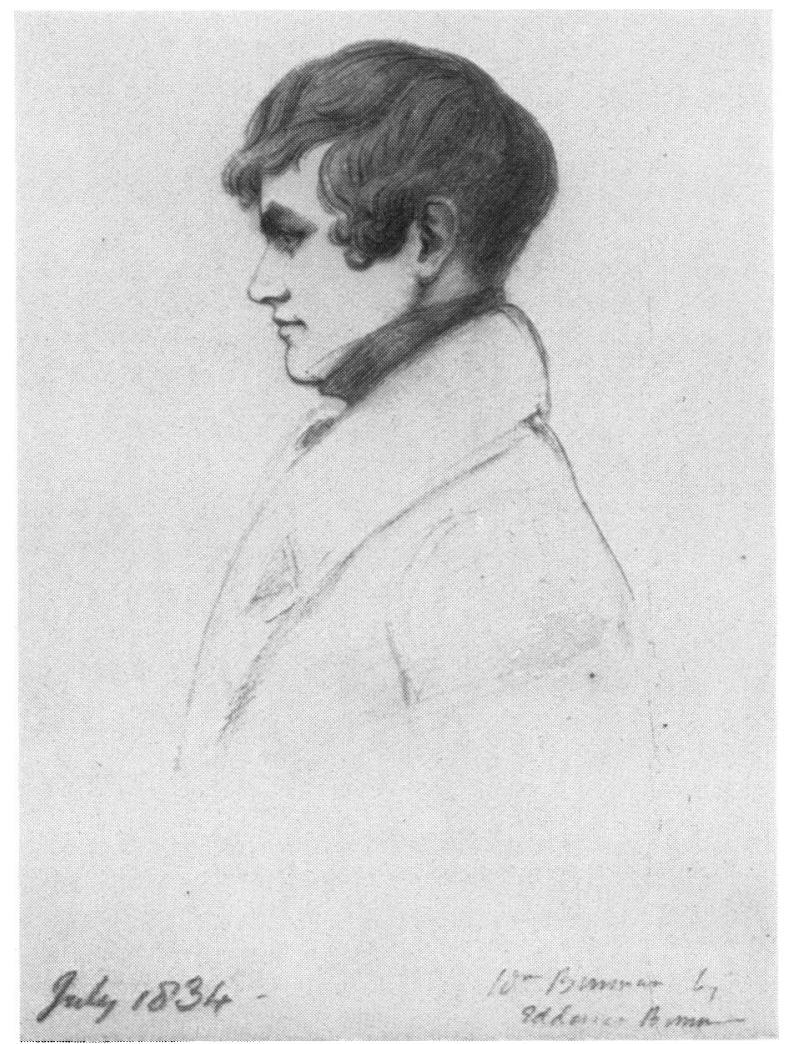

Figure 2

William Bowman, aged 18. (see p. 246). 


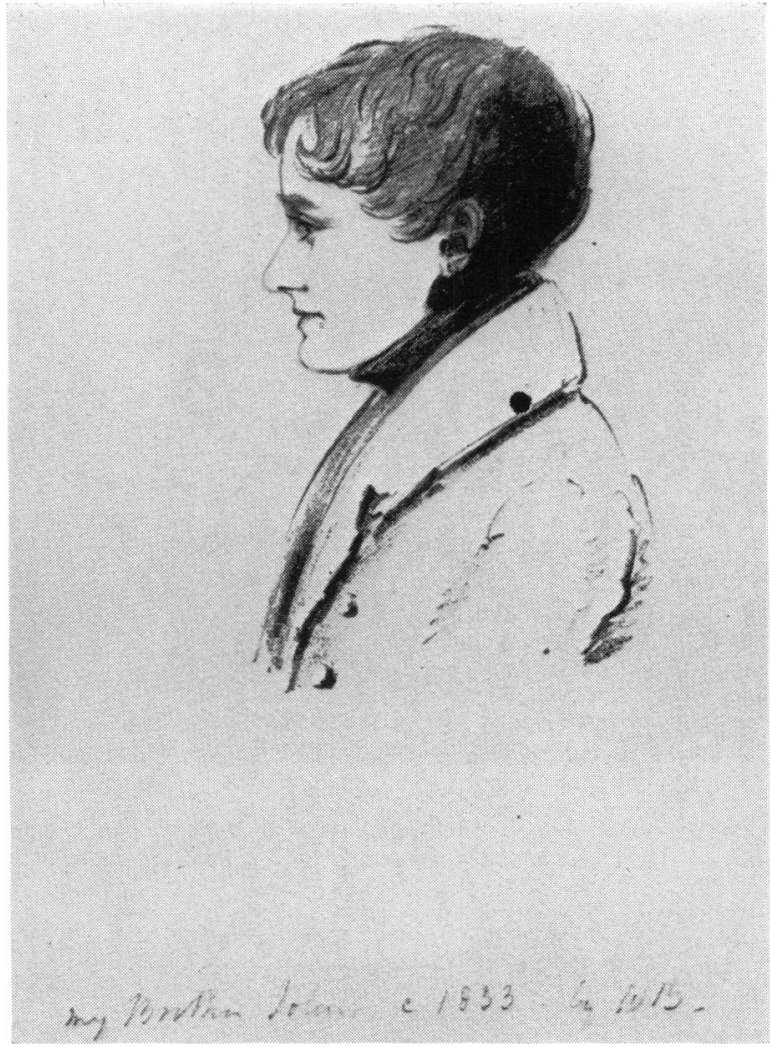

Figure 3

John Eddowes Bowman. (Sketch by William Bowman.) (see p. 246)

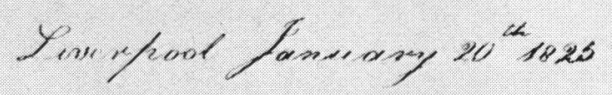

My Gowe Hother

$$
\text { Slike Siverpood ssery mett and }
$$

Sores a shife mitien Imas comeng onere the molim

phease to gene my lonse to Frathere, and I momain

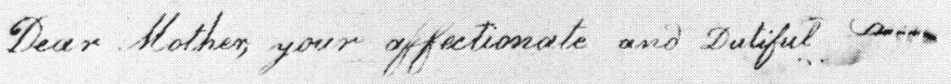

$$
\text { afy mowman }
$$

Figure 4

Letter written by William Bowman, aged 9. (see p. 246) 


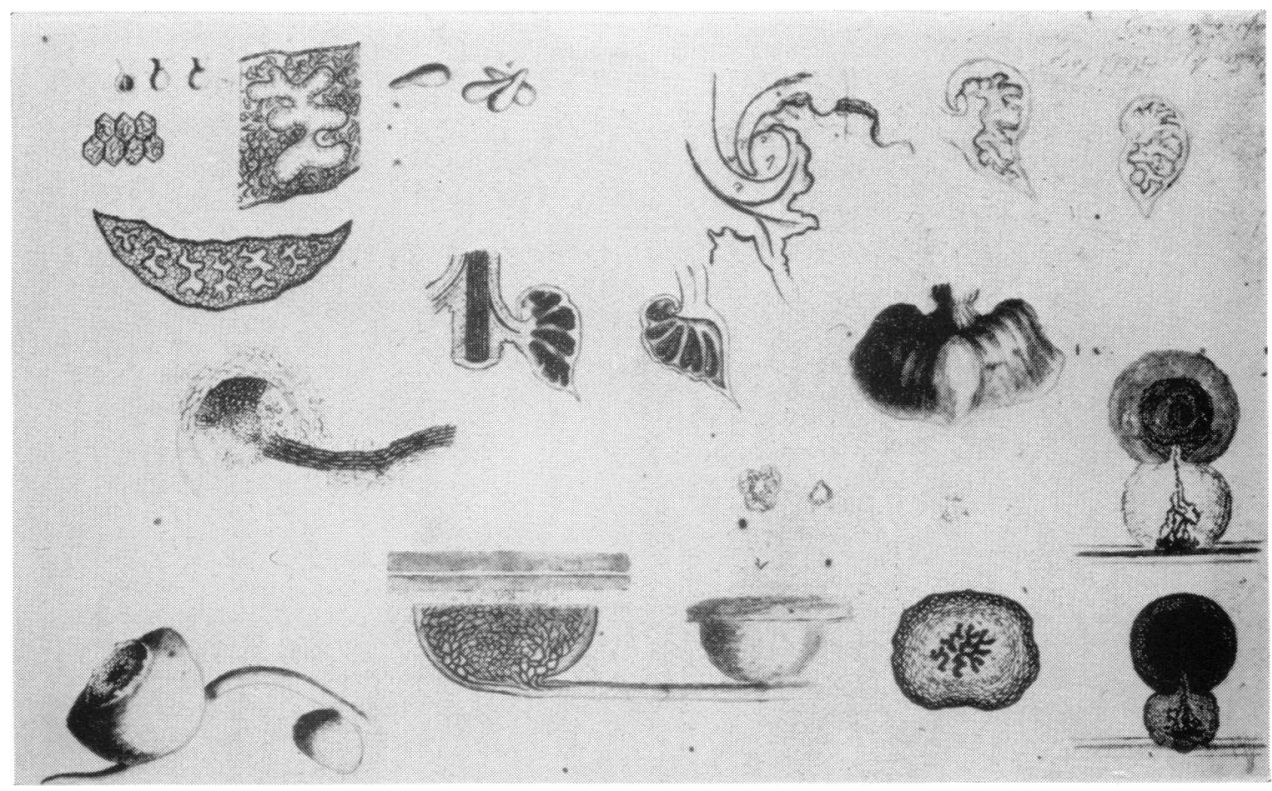

Figure 5

Photograph of pen drawing by William Bowman of renal capsule, etc., $c 1840$. (Original in the possession of Sir John Bowman.) (see p. 249)

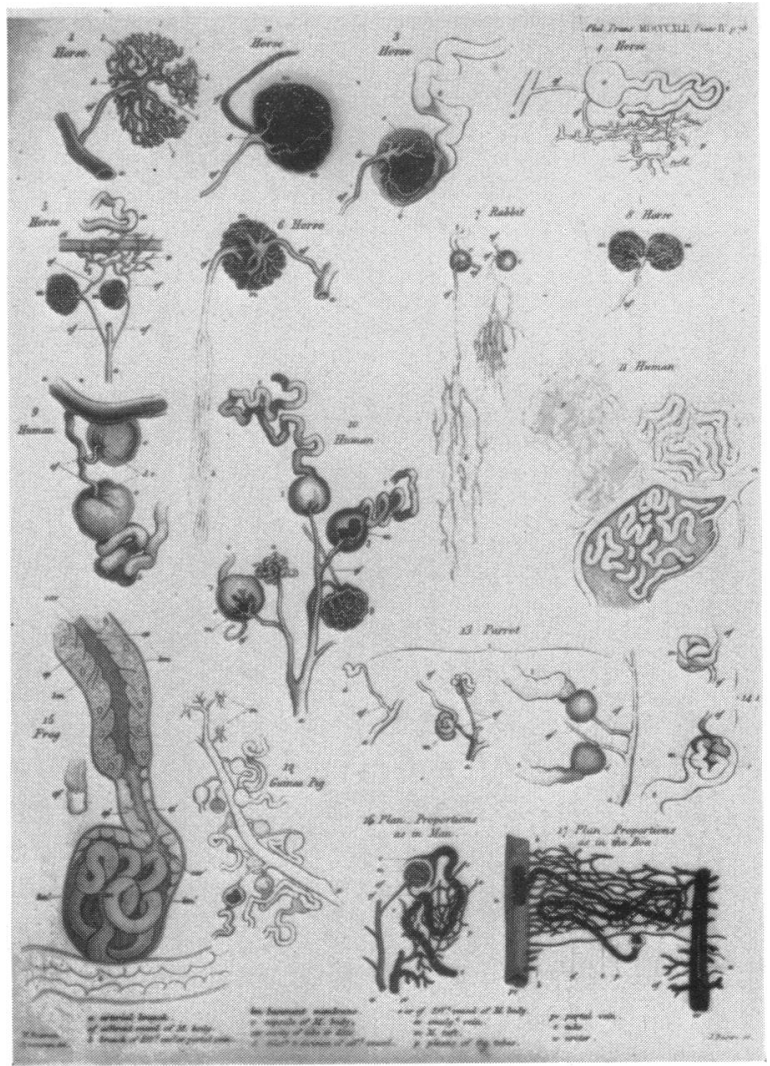

Figure 6

Drawing from Bowman's paper to the Royal Society, 17 February 1842, 'On the structure and use of the Malpighian bodies of the kidney,' Phil. Trans., 1842, p. 78, plate iv. (see p. 249) 


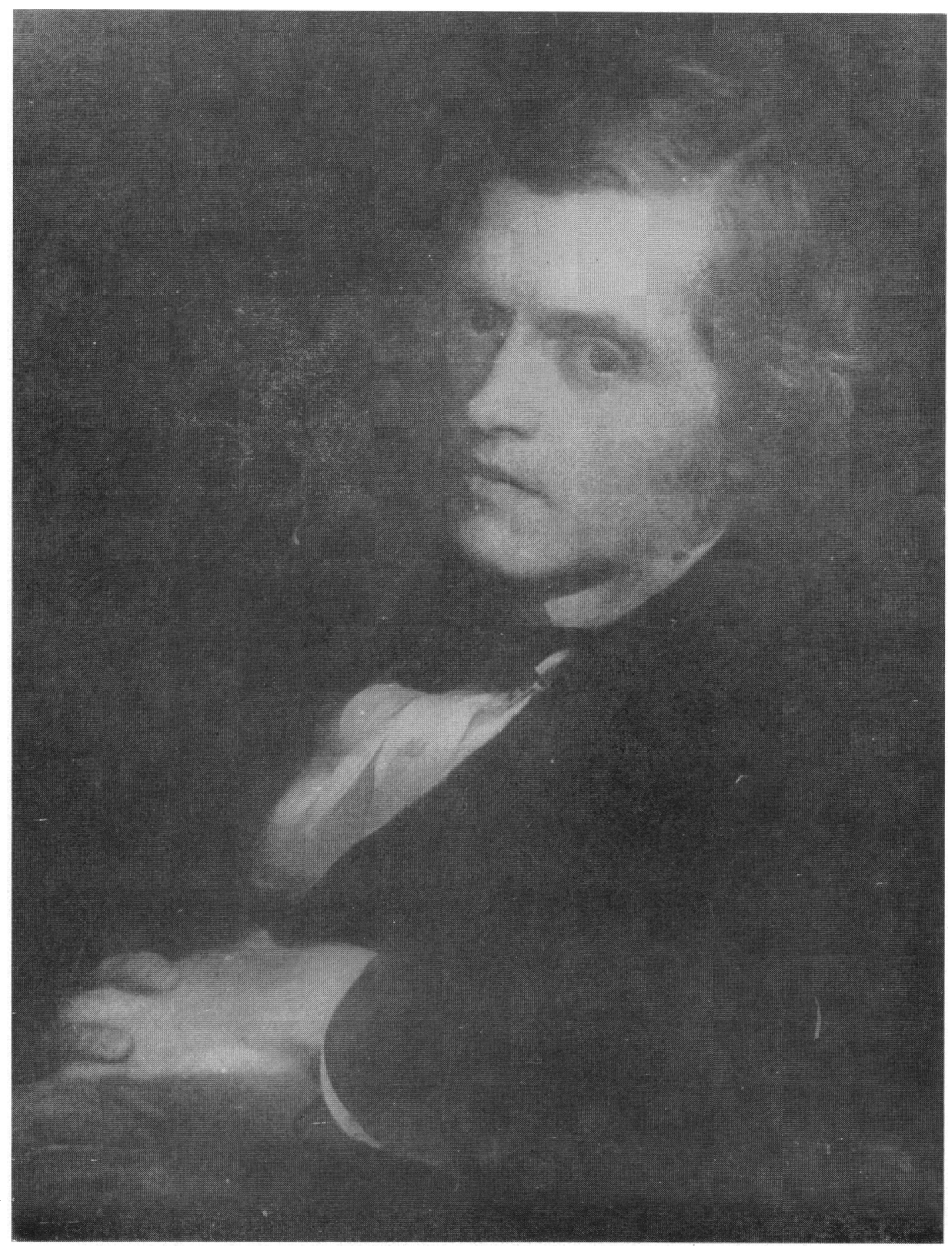

Figure 7

William Bowman, F.R.S., aged 48. (From the portrait by G. F. Watts, R.A., 1865, now in the possession of Sir John Bowman.) (see p. 250) 


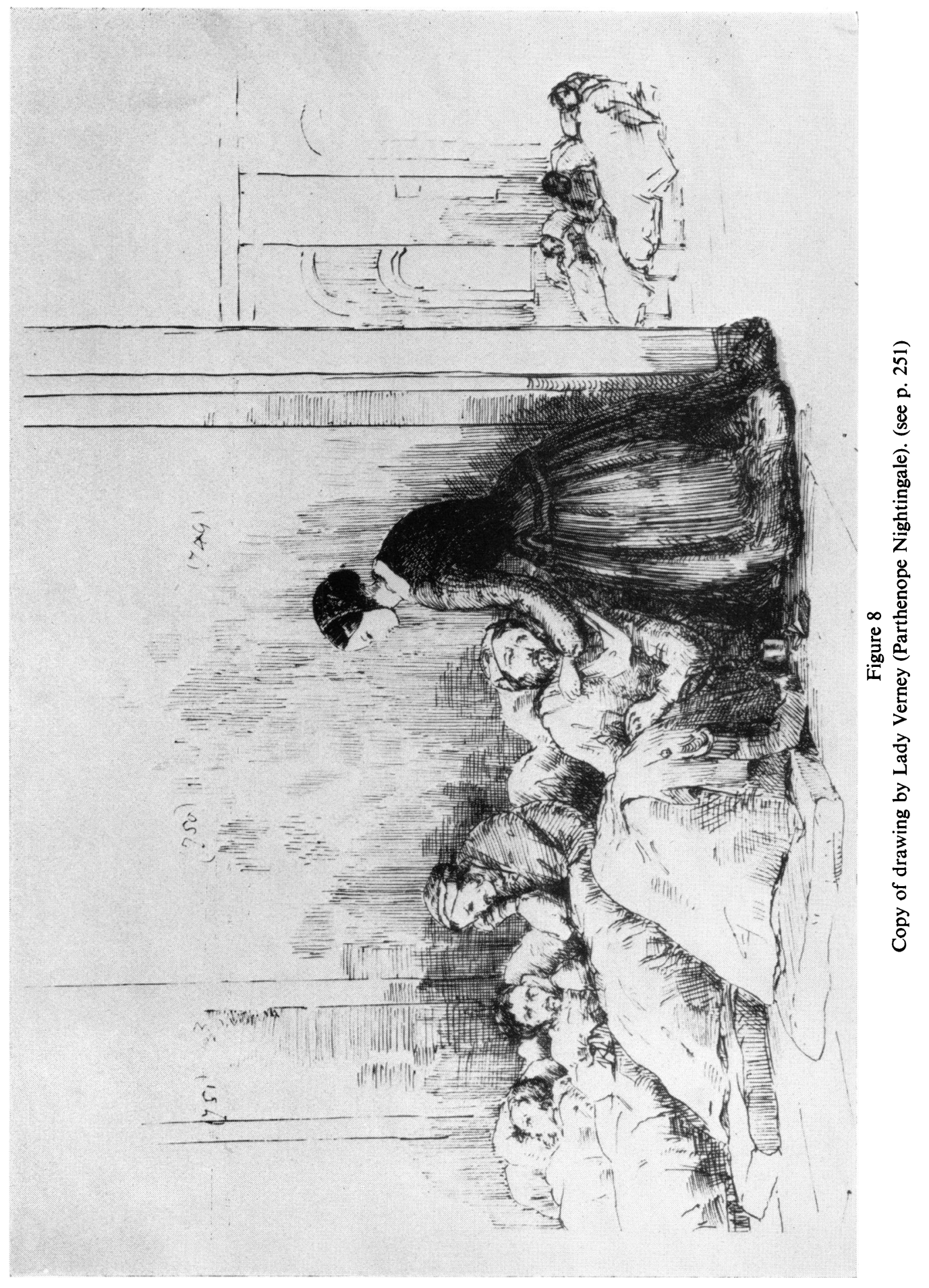




\section{The Manuscripts of Sir William Bowman}

modesty and the portraits by Watts (1865) (fig. 7) and Ouless (1889) testify to a handsome, delicate and dignified presence. Lady Bowman, his wife, had the portrait by Ouless engraved and distributed to the subscribers to the collected works ( 2 vols., 1892), and both portraits are now in the possession of his great-grandson, Sir John Bowman.

During his time in London Bowman lived in several different parts. In 1850 he moved into 5 Clifford Street, the house in which Robert Liston, the surgeon, had lived and died. From 1857 to 1871 he lived at North End, Hampstead, leaving for town a little before 9 o'clock each morning, and returning early in the evening; he was an assiduous and conscientious committee man, and a good chairman, with what d'Arcy Power described as a 'quite exceptional power of swaying men to his own way of thinking.'

A patient who had been the subject for treatment for glaucoma by many different hands, is reported to have said of him that his 'touch was the lightest and most enquiring of any.'

In later years Bowman bought a large country house, Joldwynds, between Dorking and Guildford, where he died of pneumonia on 27 March, 1892. He was buried in the nearby church of Holmbury St. Mary, within sight of the glorious Leith Hill country which he loved.

We shall now look briefly at some of the manuscripts and letters in the Bowman collection.

The Nightingale Letters. First, and most important, are the fourteen letters which Florence Nightingale wrote to Bowman between 1854 and 1870. The first of these dates means 'Crimea', and it was in fact from Scutari on November 141854 (nine days after her arrival) and from Balaclava on 28 May 1856 that the two earliest letters were written. The letter of 1870 merely introduces Capt. Lyall of the Albatross, 'a noble fellow requiring surgical treatment', but the 1854 letter is a memorable document of 12 pages describing the fearful hospital conditions at Scutari. 'On Thursday last we had 1,715 sick and wounded in this hospital (among whom were 120 cholera patients) and 650 severely wounded in the other building ... when a message came to me to prepare for 570 wounded ... who were arriving from the dreadful affair of the 5th November at Balaclava where were 1,763 wounded and 442 killed, besides 96 officers wounded and 38 killed. I always expected to end my days as hospital matron, but I never expected to be the Barrack Mistress. We had but one half hour's notice before they began landing the wounded. Between one and nine o'clock, we had the mattresses stuffed, sewn up, laid down alas! only upon matting upon the floors, the men washed and put to bed, all their wounds dressed'. This letter is so full of the detail of those terrible days that it is published here in full. (p.253).

Others of her letters mention the disposal of the money of the Nightingale Fund of which Bowman was a trustee; yet others refer to the establishment of nurses training at King's College Hospital, and another has a rough memorandum of 1858 relating to the rebuilding of the hospital on the St. Clement Danes' site, an important indication of the influence which Florence Nightingale exercised through her friends. 
There are also letters from Florence's sister, Parthenope Nightingale, as well as three of her drawings (fig. 8).

An interesting side-light on the feelings of the time with regard to Florence Nightingale, is shown by correspondence from James Young Simpson (1811-1870), famous Edinburgh obstetrician, and pioneer of chloroform. It refers to a controversy which concerned John Struthers, then lecturer in anatomy at Edinburgh (in 1863 he became Professor of Anatomy at Aberdeen). Struthers was defending his brother Alexander, who had volunteered for service in the Crimea, and who had written home somewhat critically of Florence Nightingale. John Struthers, 11 December 1854, quoted his brother to Bowman 'His complaint regarding Miss $\mathbf{N}$. and the sisters is that they interfere with the duties of the medical officers. How would we like it if the Home Office was to send some philanthropic lady in upon us at King's College Hospital or the Edinburgh Infirmary and have to wait for her at operations and by her interference to be ordered to attend first to the patient she wished whether we thought it right or not ... I suspect that however well they meant, we would vote them nuisances. So it seems to me at Scutari-they have stepped out of their proper sphere ...' Of the nurses he speaks in the highest terms, at least some of them. 'A number of Miss Nightingale's nurses are "godsends"-a greater number are a perfect nuisance. The whole thing seems to be ill managed-there is no system ...' When we remember that awful winter of 1854 , we realize that such criticisms were merely reflections of the appalling conditions under which both the doctors and the nurses had to work in the Crimea, and of the stern need which Miss Nightingale saw for the correction of abuses, both medical and administrative. We do not know what action Bowman took, if any, but Alexander Struthers died of cholera at Scutari.*

Another interesting series is made up by ten letters from Charles Darwin to Bowman written between 1866 and 1878, and another set from Frans Cornelius Donders (1818-1889) of Tilburg, Holland, the famous Dutch ophthalmologist, who became friendly with Bowman from the time they first met at the Great Exhibition in 1851.

The Darwin letters cover many topics, but one item of some interest is a series of questions which Darwin posed regarding the effect of emotions on the production of tears, and on the anatomy and physiology of the orbicularis oculi muscle. Answers to these were sought by Darwin in connection with his fascinating book The Expression of the Emotions in Man and Animals, 1872 (2nd ed., 1890) in which Chapter VI refers at some length to the expression and causes of weeping, and mentions his indebtedness to Bowman. Modern ophthalmic physiologists would not agree with all their findings, but the book makes extraordinarily interesting reading. Darwin also refers with gratitude to Bowman for having introduced Donders to him, and in a letter dated 23 January 1871, he quotes a passage from a letter from Donders on the production of tears, which is also quoted word for word on p. 174 of the 2nd ed. of The Expressions of the Emotions.

When Donders died in 1889, Bowman wrote an obituary notice for the Royal Society, and asked Donders' daughter Paula Engelmann for copies of the Darwin/ Donders correspondence. These copies too are here, several of which convey interest-

\footnotetext{
* Alexander Struthers' portrait appears in a group of Edinburgh House Surgeons 1854, which also includes Joseph Lister (see Guthrie, D. A History of Medicine, 1945, pl. 63).
} 


\title{
The Manuscripts of Sir William Bowman
}

ing hints. For instance, on 18 March 1871, Darwin wrote to Donders, 'It is clear to me that you were as near as possible in preceding me in the subject of natural selection. You will find very little that is new to you in my last book' (i.e. The Descent of Man, 1871). Donders seems to have written on natural selection in 1847, but as his book was published in Dutch, it attracted little attention. In another note, from Down, 17 June 1872, Darwin wrote regarding the proofs of his book on Expression, 'I will consult you if in doubt upon special points . . . The chapter which I thought most dangerous, viz. that on weeping, was read over in manuscript some time ago by Mr. Bowman, so I feel pretty safe about this chapter'. In 1869, Bowman had taken Donders to Down to visit the great man, and the friendship of these three scientists illustrates the natural way in which scientific interest crosses national boundaries and overflows into mutual esteem.

\section{ACKNOWLEDGEMIENT}

I am greatly indebted to Sir John Bowman, Bart., of Newbury for permission to peruse and reproduce the documents of his great-grandfather in his possession. These have now been listed and briefly catalogued. I am also grateful to Sir John Bowman for permission to publish Miss Nightingale's letter.

\section{A CRIMEAN LETTER: FLORENCE NIGHTINGALE TO SIR WILLIAM BOWMAN}

'I came out Ma'am, prepared to submit to everything - to be put upon in every way-but there are some things, Ma'am, one can't submit to-There is caps, Ma'am, that suits one face and some that suits anothers, and if I'd known, Ma'am, about the caps, great as was my desire to come out to nurse at Scutari, I wouldn't have come Ma'am.'

Speech of Mrs. Lawfield, Nov. 5th.

\author{
Barrack Hospital, \\ Scutari, \\ Asiatic Side. \\ Nov. 141854
}

Dear Sir,

Time must be at a discount with the man who can adjust the balance of such an important question as the above-and I, for one, have none, as you will easily suppose when I tell you that on Thursday last we had 1,715 sick and wounded in this hospital (among whom 120 Cholera Patients), and 650 severely wounded in the building, called the General Hospital, of which we also have charge-when a message came to me to prepare for $\mathbf{5 7 0}$ wounded on our side of the Hospl, who were arriving from the dreadful affair of the fifth Novber at Balaklava, where were 1,763 wounded, and 442 killed, besides 96 officers wounded and 38 killed. I always expected to end my days as hospital matron but I never expected to be Barrack Mistress. We had but half an hour's notice before they began landing the wounded-Between one and nine o'clock, we had the mattresses stuffed, sewn up, laid down, alas! only upon matting on the floors, the men washed and put to bed, and all their wounds dressedI wish I had time and I would write you a letter dear to a Surgeon's heart, I am as good as a "Medical Times". 


\section{K. Bryn Thomas}

But Oh! you gentlemen of England, who sit at home in all the well-earned satisfaction of your successful cases, can have little idea, from reading the newspapers, of the horror and misery (in a Military Hospl) of operating upon these dying and exhausted men-a London Hospl is a garden of flowers to it-we have had such a sea in the Bosphorus, and the Turks, the very men for whom we are fighting, carry our wounded so cruelly, that they arrive in a state of agony-one amputated stump died two hours after we received him-one compound fracture just as we were getting him into bed, in all twenty-four cases on the day of landing-the dysentery cases have died at the rate of one in two-then the day of operations which follows-I have no doubt that Providence is quite right and that the Kingdom of Hell is the best beginning for the Kingdom of Heaven, but that this is the Kingdom of Hell no one can doubt. We are very lucky in our Medical Heads-two of them are brutes, and four of them are angels-for this is a work which makes either angels or devils of men, and of women too-As for the Assistants, they are all cubs, and will, while a man is breathing his last breath under the knife, lament the 'arrogance of being called up from their dinners by such a fresh influx of wounded'. But wicked cubs grow up into good old bears, tho' I don't know how-for certain it is, the old bears are good. We have now four miles of beds-and not eighteen inches apart-We have our quarters in one Tower of the Barrack-and all this fresh influx has been laid down between us and the Main Guard in two corridors with a line of beds down each side, just room for one man to step between, and four wards.

Yet, in the midst of this appalling horror (we are steeped up to our necks in blood)there is good-And I can truly say, like St. Peter, 'it is good for us to be here'-though I doubt whether, if St. Peter had been here, he would have said so-As I went my night rounds among the newly wounded that first night, there was not one murmur, not one groan, the strictest discipline, the most absolute silence and quiet prevailedonly the step of the sentry and I heard one man say, I was dreaming of my friends at home, and another said, And I was thinking of them-These poor fellows bear pain and mutilation with unshrinking heroism, and die or are cut up without a complaint. Not so the Officers, but we have nothing to do with the Officers-The wounded are now lying up to our very door, and we are landing 540 more from the "Andes"-I take rank in the Army as Brigadier-General, because 40 British females, whom I have with me are more difficult to manage than 4,000 men-Let no lady come out here who is not used to fatigue and privation-For the Devonport Sisters, who ought to know what self-denial is, do nothing but complain-Occasionally the roof is torn off our quarters, or the windows blown in-and we are flooded and under water for the night. We have all Sick Cookery now to do, and have got in four men for the purpose, for the prophet Mahomet does not allow us a female. And we are now able to supply these poor fellows with something besides the Govt Rations-The climate is very good for the healing of wounds.

I wish you would recall me to Dr. Bence Jones's remembrance, when you see him, and tell him that I have had but too much occasion to remember him in the constant use of his dreadful presents. Now comes the time of haemorrhage and Hospital Gangrene, and every ten minutes an orderly runs, and we have to go and cram lint into the wound till a Surgeon can be sent for, and stop the bleeding as well as we 


\section{The Manuscripts of Sir William Bowman}

can-In all our Corridors I think we have not an average of three limbs per manand there are two ships more "loading" at the Crimea with wounded, this is our phraseology. Then come the operations and a melancholy, not an encouraging list is this-They are all performed in the wards-no time to move them. One poor fellow, exhausted with haemorrhage, has his leg amputated as a last hope and dies ten minutes after the surgeons have left him-Almost before the breath has left his body, it is sewn up in its blanket and carried away-buried the same day. We have no room for corpses in the wards. The Surgeons pass on to the next, an excision of the shoulder-joint—-beautifully performed and going on well—ball lodged just in the head of the joint, and fracture starred all round-The next poor fellow has two stumps for arms-and the next has lost an arm and leg. As for the balls, they go in where they like, and do as much harm as they can in passing-That is the only rule they have. The next case has one eye put out, and paralysis of the iris of the other. He can neither see nor understand. But all who can walk come into us for Tobacco, but I tell them that we have not a bit to put into our own mouths-Not a sponge, nor a rag of linen, not an anything have I left. Everything is gone to make slings and stump pillows and shirts. These poor fellows have not had a clean shirt nor been washed for two months before they came here, and the state in which they arrive from the transport is literally crawling. I hope in a few days we shall establish a little cleanliness-But we have not a basin nor a towel nor a bit of soap nor a broom-I have ordered 300 scrubbing brushes. But one half the Barrack is so sadly out of repair that it is impossible to use a drop of water on the stone floors, which are all laid upon rotten wood, and would give our men fever in no time-The next case is a poor fellow where the ball went in at the side of the head, put out one eye, made a hole in his tongue and came out in the neck. The wound was doing very nicely when he was seized with agonizing pain and died suddenly, without convulsion or paralysis. At the P.M., an abscess in the anterior part of the head was found as big as my fist-yet the man kept his reasoning faculties till the last. And nature had thrown out a false coat all round it.

I am getting a screen now for the Amputations, for when one poor fellow, who is to be amputated tomorrow, sees his comrade today die under the knife it makes impression-and diminishes his chance-But, anyway, among these exhausted frames the mortality of the operations is frightful-We have Erysipelas Fever and Gangrene -And the Russian wounded are the worst. We are getting on nicely though in many ways. - They were so glad to see us. The Senior Chaplain is a sensible man, which is a remarkable providence-I have not been out of the hospital wards yet. But the most beautiful view in the world lies outside-If you ever see Mr. Whitfield, the House Apothecary of St. Thomas's, will you tell him that the nurse he sent me, Mrs. Roberts, is worth her weight in gold. There was another engagement on the 8th, and more wounded, who are coming down to us-The text which heads my letter was expounded thus-Mrs. Lawfield was recommended to return home and set her cap, vulgarly speaking, at some one elsewhere than here, but on begging for mercy, was allowed to make another trial-Mrs. Drake is a treasure-the four others are not fit to take care of themselves nor of others in a Military Hospt. This is my first impression. But it may modify, If I can convince them of the absolute necessity of discipline and propriety in a drunken Garrison. 


\section{K. Bryn Thomas}

Continued on inside flap of envelope:

Believe me, dear Sir, yours very truly and gratefully,

Florence Nightingale

This is only the beginning of things. We are still expecting the assault.

The above letter, which needs no comment or annotation, is now in the possession of Sir John Bowman, great-grandson of Sir William Bowman (1816-1892) to whom it was addressed. It has not appeared in full previously, a small portion only being reproduced, without reference, by Woodham-Smith'

Florence Nightingale had arrived in the Crimea on 5 November 1854, nine days before this letter was written, and shortly after the disastrous charge of Balaclava, which she mentions. (The action in fact took place on 25 October).

The party of forty nurses had left London on Saturday, 21 October, travelling overland from Boulogne to Marseilles, and by an uncomfortable and dirty mail boat, the Vectis, to Constantinople. On the second day out, the ship ran into a storm, and Miss Nightingale, a poor sailor, was prostrated for the remainder of the four days' voyage.

Upon arrival at Scutari, the nurses found indescribable conditions of neglect, sickness and lack of supplies, and, as her letter shows, on Thursday, 9 November the wounded from Balaclava arrived.

Yet amid this incredible turmoil this indomitable lady found time to write a letter of twelve arresting pages to her old friend and supporter, Sir William Bowman.

${ }^{1}$ Woodham-Smith, C., Florence Nightingale. Reprint Socy. London, 1952, p.131. 